OPEN ACCESS

Edited by:

Mukesh Kumar Awasthi, Northwest A\&F University, China

Reviewed by: Parveen Fatemeh Rupani, Jiangsu University, China Md. Akter Hosen,

Dhofar University, Oman Jianfeng Yang,

Northwest A\&F University, China

*Correspondence:

Shams Forruque Ahmed shams.ahmed@auw.edu.bo shams.f.ahmed@gmail.com Nazifa Rafa

nazifa.rafa@post.auw.edu.bd M. Mofijur mdmofjur.rahman@uts.edu.au

Specialty section: This article was submitted to Bioenergy and Biofuels, a section of the journal Frontiers in Energy Research

Received: 05 August 2021 Accepted: 27 August 2021 Published: 10 September 2021

Citation:

Ahmed SF, Rafa N, Mofijur M, Badruddin IA, Inayat A, Ali MS, Farrok O and Yunus Khan TM (2021) Biohydrogen Production From

Biomass Sources: Metabolic Pathways and Economic Analysis.

Front. Energy Res. 9:753878. doi: 10.3389/fenrg.2021.753878

\section{Biohydrogen Production From Biomass Sources: Metabolic Pathways and Economic Analysis}

\author{
Shams Forruque Ahmed $^{1 *}$, Nazifa Rafa ${ }^{2 *}$, M. Mofijur ${ }^{3,4 *}$, Irfan Anjum Badruddin ${ }^{5}$, \\ Abrar Inayat ${ }^{6,7}$, Md Sawkat $A i^{8}{ }^{8}$ Omar Farrok $^{9}$ and T. M. Yunus Khan ${ }^{5}$
}

\begin{abstract}
${ }^{1}$ Science and Math Program, Asian University for Women, Chattogram, Bangladesh, ${ }^{2}$ Environmental Sciences Program, Asian University for Women, Chattogram, Bangladesh, ${ }^{3}$ Centre for Green Technology, School of Civil and Environmental Engineering, University of Technology Sydney, Sydney, NSW, Australia, ${ }^{4}$ Mechanical Engineering Department, Prince Mohammad Bin Fahd University, Al Khobar, Saudi Arabia, ${ }^{5}$ Mechanical Engineering Department, College of Engineering, King Khalid University, Abha, Saudi Arabia, ${ }^{6}$ Department of Sustainable and Renewable Energy Engineering, University of Sharjah, Sharjah, United Arab Emirates, ${ }^{7}$ Biomass and Bioenergy Research Group, Center for Sustainable Energy and Power Systems Research, Research Institute of Sciences and Engineering, University of Sharjah, Sharjah, United Arab Emirates, ${ }^{8}$ Department of Computer Science and Engineering, East West University, Dhaka, Bangladesh, ${ }^{9}$ Department of Electrical and Electronic Engineering, Ahsanullah University of Science and Technology, Dhaka, Bangladesh
\end{abstract}

The commercialization of hydrogen as a fuel faces severe technological, economic, and environmental challenges. As a method to overcome these challenges, microalgal biohydrogen production has become the subject of growing research interest. Microalgal biohydrogen can be produced through different metabolic routes, the economic considerations of which are largely missing from recent reviews. Thus, this review briefly explains the techniques and economics associated with enhancing microalgae-based biohydrogen production. The cost of producing biohydrogen has been estimated to be between $\$ 10 \mathrm{GJ}^{-1}$ and $\$ 20 \mathrm{GJ}^{-1}$, which is not competitive with gasoline $\left(\$ 0.33 \mathrm{GJ}^{-1}\right)$. Even though direct biophotolysis has a sunlight conversion efficiency of over $80 \%$, its productivity is sensitive to oxygen and sunlight availability. While the electrochemical processes produce the highest biohydrogen (>90\%), fermentation and photobiological processes are more environmentally sustainable. Studies have revealed that the cost of producing biohydrogen is quite high, ranging between $\$ 2.13 \mathrm{~kg}^{-1}$ and $7.24 \mathrm{~kg}^{-1}$ via direct biophotolysis, $\$ 1.42 \mathrm{~kg}^{-1}$ through indirect biophotolysis, and between $\$ 7.54 \mathrm{~kg}^{-1}$ and $7.61 \mathrm{~kg}^{-1}$ via fermentation. Therefore, lowcost hydrogen production technologies need to be developed to ensure long-term sustainability which requires the optimization of critical experimental parameters, microalgal metabolic engineering, and genetic modification.

Keywords: microalgae, dark fermentation, photofermentation, biophotolysis, techno-economic analysis, renewable energy

\section{INTRODUCTION}

The energy crisis has emerged as the most significant impediment to the advancement of human civilisation (Ahmed S. F. et al., 2021). Rapidly diminishing fossil fuel reserves have been posing a threat to the world's energy security (Mahlia et al., 2020). Therefore, attempts have been made to transition away from an overreliance on fossil fuels and utilize renewable energy sources such as solar 
energy, wind energy, geothermal energy, biogas (Mahmudul et al., 2020), ethanol, and biodiesel (Mofijur et al., 2020). With a production of 55 million tonnes every year, hydrogen is an important eco-friendly industrial feedstock due to its high energy density (Wang and Yin, 2018; Bolatkhan et al., 2019; Gielen, 2019). The hydrogen market is experiencing up to $10 \%$ growth year on year and is forecast to reach over $\$ 191.80$ billion in 2024 (Bolatkhan et al., 2019; Nagarajan et al., 2021). However, the commercialization of hydrogen as a fuel suffers major bottlenecks in terms of the techno-economic and environmental feasibility of conventional methods (Das et al., 2019), the dependence on fossil fuels to drive some processes (Dawood et al., 2020), and challenges related to transportation and storage (Nagarajan et al., 2017; Abdalla et al., 2018). Biological techniques for hydrogen synthesis, such as using organisms like microalgae, can effectively address these limitations. Unlike most biological sources, microalgae have many benefits, such as a high growth rate (Muhammad et al., 2021), low requirements for energy, high-quality land and water; a lower environmental impact (Ahmed SF. et al., 2021); and the absence of a need for costly pretreatment processes due to the lack of lignin (Singh and Das, 2020).

Microalgal biohydrogen production has occupied much interest, especially in recent years after it was revealed that various useful metabolites are also produced as co-products (Siddiki et al., 2020). Nevertheless, difficulties in process engineering, low productivity of microalgae, oxygen sensitivity, and operational costs, and inadequate insights on strain capacity, hinder the commercialization of microalgae-based biohydrogen production. Even though there are several metabolic routes to produce biohydrogen from microalgae with an improved yield, recent reviews (Buitrón et al., 2017; Sharma and Arya, 2017; Shobana et al., 2017; Show et al., 2018; Razu et al., 2019; Show et al., 2019b; El-Dalatony et al., 2020; Jiménez-Llanos et al., 2020; Mona et al., 2020; Salakkam et al., 2021) have not provided the comprehensive economic evaluation of such strategies, which has resulted in a dearth in the understanding of process feasibility. Therefore, in addressing this knowledge gap, this mini-review explicates the metabolic routes that enhance microalgae-based biohydrogen production and provides insights into their economic considerations to guide future work in the scaling-up of these technologies.

\section{METABOLIC PATHWAYS OF BIOHYDROGEN PRODUCTION FROM BIOMASS SOURCES}

Biohydrogen production, as an alternative to many conventional energy sources (Foong et al., 2020), is viewed as a strong prospective contender in the energy economy (Wang and Yin, 2018). Microalgae biomass is frequently utilized to generate various types of bioenergy (Ge et al., 2020), with biohydrogen being one of the most promising categories of bioenergy that can be generated from microalgae. Biohydrogen can be generated from microalgae using two alternative processes: i) direct production of biohydrogen by microalgae, and ii) microalgal biomass utilisation as a fermentation substrate by other microbes. The first process can produce biohydrogen ranging from 0.015 to $1.084 \mathrm{mmol} / \mathrm{L}$.h whereas for the second process this may vary from 0.35 to $10.26 \mathrm{mmol} / \mathrm{L} . \mathrm{h}$, depending on the feedstocks, culture conditions, and microorganisms used (Oncel, 2015). However, these two processes can be combined to improve the biohydrogen production rate. The metabolic pathways of biohydrogen production from microalgae are illustrated in Figure 1. These technologies for producing biohydrogen using microalgae are discussed in the following sub-sections.

\section{Fermentation Process}

Biohydrogen production using the fermentation process is found to be effective as it is environmentally friendly, puts less pressure on the consumption of fossil fuel, and controls pollution. Therefore, this method of producing hydrogen has huge potential as an alternative to fossil fuels. The fermentation process can be separated into dark fermentation and photofermentation.

\section{Photofermentation}

Photofermentation refers to fermentation processes that employ sunlight as an energy source for photosynthesis. Instead of using sugar, this pathway utilises light as a source of energy. Therefore, photofermentation is advantageous compared to other pathways. Hydrogen production by photofermentation is described by the following equation (Baeyens et al., 2020):

$$
\begin{aligned}
& 16 A T P+\mathrm{N}_{2}+16 \mathrm{H}_{2} \mathrm{O}+10 \mathrm{H}^{+}+8 \bar{e} \rightarrow 16 \mathrm{ADP}+2 \mathrm{NH}_{4}^{+} \\
& +16 \mathrm{pi}+\mathrm{H}_{2}
\end{aligned}
$$

For this pathway, instead of water, the green algae gain electrons from heterotrophic fermentation and the catabolic reaction of the endogenous substrate. Electrons are separated from organic substrate products by photocatabolism. Light energy and oxidative carbon metabolism also play a role in the extraction of electrons. Here $\mathrm{e}^{-}$is generated from the endogenous substrates using catabolism. These electrons undergo the plastoquinone (PQ) pool which is situated in Photosystem I (PSI) and Photosystem II (PSII). The transfer of electrons to the PQ pool is associated with nicotinamide adenine dinucleotide phosphate (NADPH)- plastoquinone oxidoreductase (PQOR) in the chloroplast of different types of vascular plants (Dalena et al., 2017). In this process, PSI assimilates light energy and generates electrons. The redox potential of this electron can be elevated through the transfer of these electrons to the corresponding level of $[\mathrm{Fe}]-\mathrm{H}_{2}$ ase and ferredoxin (FDX) (Mosebach et al., 2017).

The dark and anoxic environment induce ([Fe]- $\mathrm{H}_{2}$ ase) and help to produce a high yield of biohydrogen. When DCMU (3(3,4-dichlorophenyl)-1,1-dimethylurea) is present, incubating microalgae culture in these conditions is beneficial for biohydrogen production (El-Dalatony et al., 2020; Mu et al., 2020). Compared to dark fermentation, photofermentation is 


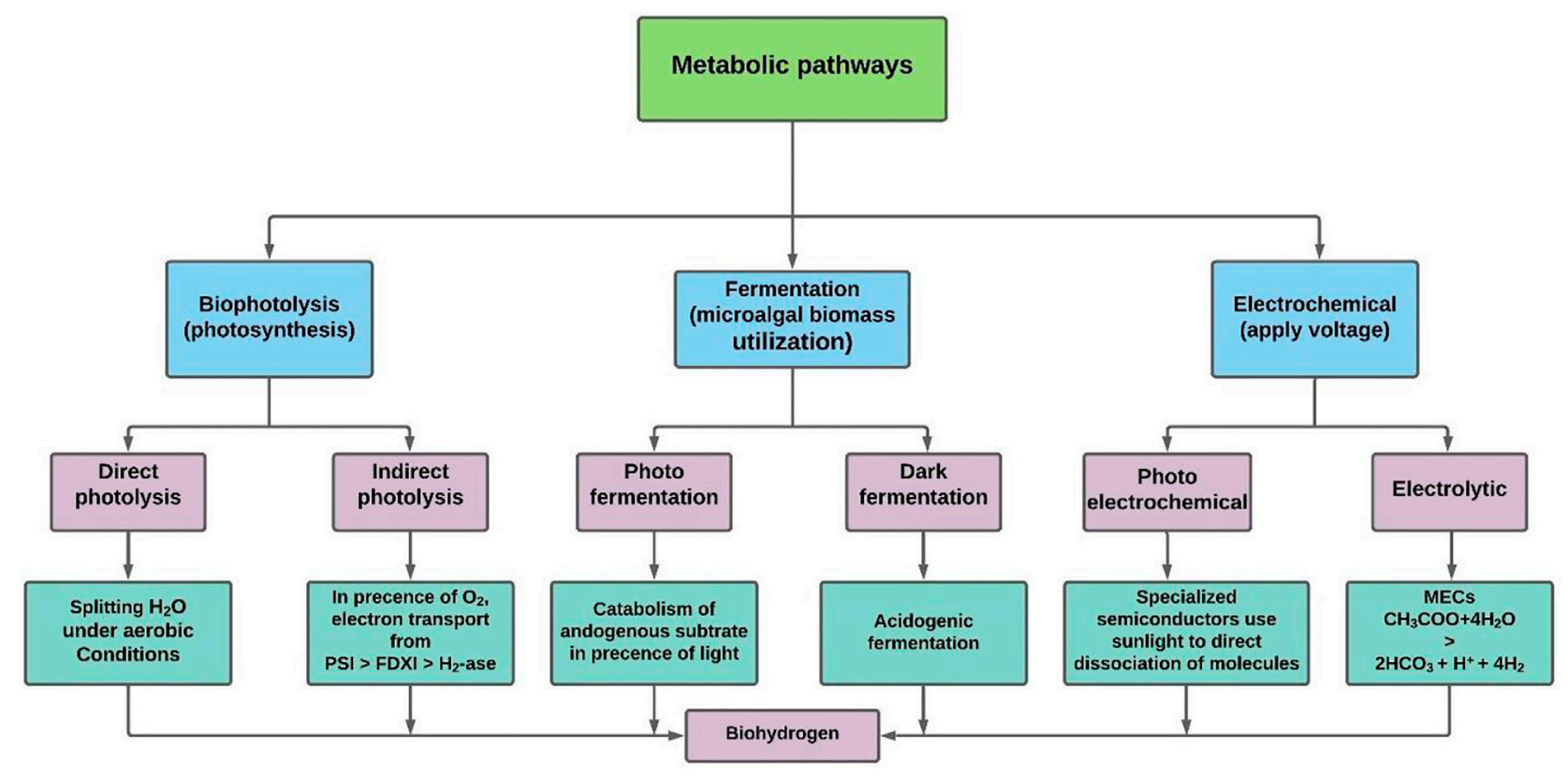

FIGURE 1 | Metabolic pathways of biohydrogen production by micro-algal biomass, modified from El-Dalatony et al. (2020). These are mainly classified into three categories: i) the photobiological process through which biohydrogen is produced via direct and indirect photolysis in the microalgae; ii) fermentation; and iii) the electrochemical process that comprises photoelectrochemical and electrolytic.

considered a better process to produce biohydrogen. Zhang et al. (2020) compared dark-photo fermentation, photo fermentation and dark fermentation in terms of biohydrogen production. Photo fermentation was found to be the most effective as it had a high hydrogen content (maximum 58.90\%), and the efficiency in energy conversion (10.12\%) was found to be the highest in this method. In terms of hydrogen yield, photo fermentation was also found to be effective compared to the other two pathways. Photo fermentation achieved the maximum hydrogen yield of $141.42 \mathrm{ml}(\mathrm{g} \text { TS })^{-1}$ while dark fermentation generated the minimum hydrogen yield of $36.08 \mathrm{ml}(\mathrm{g} \mathrm{TS})^{-1}$. Therefore, the photo fermentation process can be a good choice in producing biohydrogen. However, compared to biophotolysis and electrochemical processes, it has low efficiency in sunlight conversion and biohydrogen yield.

\section{Dark Fermentation}

The dark fermentation pathway is light-independent. It performs heterotrophic fermentation using microbes or microalgae. Green algae rich in carbohydrates are the most common type of microalgae used to produce biohydrogen in this process (Banu et al., 2020). Substrates such as glucose, sucrose, starch, and cellulose are used to enhance the production rate of hydrogen. $1 \mathrm{~mol}$ of glucose gives $12 \mathrm{~mol}$ hydrogen atoms through complete conversion:

$$
\mathrm{C}_{6} \mathrm{H}_{12} \mathrm{O}_{6}+6 \mathrm{H}_{2} \mathrm{O}=12 \mathrm{H}_{2}+6 \mathrm{CO}_{2}
$$

This produces $4 \mathrm{~mol}$ of hydrogen through the method of dark fermentation. The by-products of the reaction are organic acids (Mona et al., 2020):

$$
\mathrm{C}_{6} \mathrm{H}_{12} \mathrm{O}_{6}+6 \mathrm{H}_{2} \mathrm{O}=2 \mathrm{CH}_{3} \mathrm{COOH}+4 \mathrm{H}_{2}+2 \mathrm{CO}_{2}
$$

The dark fermentation method involves converting complex matter into simpler products through hydrolysis (Kucharska et al., 2019), for instance, complex carbohydrates into reducing sugars. These simple compounds then go through acidification instigated by enzymes. Fermentative bacteria secrete these types of enzymes. In the next stage, these acid products further transform into biohydrogen and acetate through a process called acetogenesis. It is essential to stop the progress of the methanogenesis and collect biohydrogen produced in the prior steps for the production of biohydrogen in the same pathway (Osman et al., 2020).

In the process of dark fermentation, biohydrogen is produced by two mechanisms. One of them is by a catabolic transformation of formic acid while the other one is through re-oxidation of nicotinamide adenine dinucleotide hydride (NADH), which is catalysed by the $\mathrm{H}_{2}$ ase pathway (El-Dalatony et al., 2020). Pyruvate ferredoxin oxidoreductase (PFR) is used to catalyse pyruvate oxidation. Consequently, there is a need to stabilize the oxidative-reductive reaction. This can be done through the production of compounds like butanol and ethanol from the transformation of NADH (Wang et al., 2020). Biohydrogen produced by the dark fermentation process has a comparatively higher rate and amount than other methods. The issue is with the low hydrogen concentration of about $40-60 \%$. For this, without a purification step, the fermentative effluent gas cannot be used by the fuel cells (Mona et al., 2020).

To enhance the performance of the dark fermentation process, Song et al. (2020) employed enzymolysis and acid pretreatment to discharge reducing sugars from $A$. philoxeroides. The reducing 
yield of sugar was found to be $0.35 \mathrm{~g} / \mathrm{g}$ A. philoxeroides under the optimal pretreatment condition, and after enzymolysis, it was increased further to $0.56 \mathrm{~g} / \mathrm{g}$ A. philoxeroides. As a result, an increase of $59.9 \%$ in biohydrogen yield was achieved for the pretreated A. philoxeroides. Optimizing bacteria suspensions, the maximum production rate of biohydrogen was increased to 4.64 from $1.42 \mathrm{ml} / \mathrm{gVS} / \mathrm{h}$, which accelerated the biohydrogen yield peak and contributed to a $42.8 \%$ increase in the biohydrogen production to $89.8 \mathrm{ml} / \mathrm{gVS}$. However, attention needs to be paid to the by-products of $A$. philoxeroides pretreatment and their influence on biohydrogen generation, which were not addressed in this study.

\section{Biophotolysis Process}

In the biophotolysis process, solar energy is used by photosystem II to break water into oxygen, energy, and a reducing agent. This agent is used to produce hydrogen by reducing protons utilizing nitrogenase or hydrogenase enzymes. Electrons gained from breaking water pass through the electron transport chain consisting of PSI and PSII. Then it produces adenosine triphosphate (ATP) and reduces the ferredoxin compound. These take part in various metabolic reactions to produce hydrogen (Razu et al., 2019). The biophotolysis process is divided into two categories: indirect and direct biophotolysis. Endogenous substrates catabolize and produce electrons which are used in indirect biophotolysis whereas direct biophotolysis utilizes the electrons produced from the splitting of water in photosystem II.

\section{Direct Biophotolysis}

In the process of direct biophotolysis, water molecules are split using sunlight as a source of energy in the PSII. After transferring the residual $\mathrm{e}^{-}$to photosystem $\mathrm{I}$, the hydrogenase helps to produce hydrogen without generating harmful greenhouse gases. This process also simultaneously releases oxygen into the atmosphere (Jiménez-Llanos et al., 2020). The reaction for this process is as follows (Kumar S et al., 2019):

$$
2 \mathrm{H}_{2} \mathrm{O}+\text { light energy } \rightarrow 2 \mathrm{H}_{2}+\mathrm{O}_{2}
$$

In the direct biophotolysis pathway, the oxidation of water molecules via the PSII produces electrons. The photons gained from sunlight are used by the PSII. to power the electrons These energized electrons then move through the electron transport chain. Ferredoxin (Fd) and PSI assist the transfer of electrons. $\mathrm{NADP}+$ is reduced to nicotinamide $\mathrm{NADPH}$ by plastoquinol produced through electron transfer. To form $\mathrm{O}_{2}$ and $\mathrm{H}^{+}$, the electrons are substituted by oxidizing water. These electrons gained from water are used for photosynthesis by photosystem II. A proton gradient is needed to generate ATP through ATP synthase. These protons act as the terminal acceptors for the electrons in the chloroplast of the algae. As a result, this process produces hydrogen and oxygen gases simultaneously (Show et al., 2019a).

Green microalgae are noted as the only microorganism that undergoes direct biophotolysis in the absence of oxygen in the production of biohydrogen by splitting water. Green microalgae and cyanobacteria are referred to as "oxygenic photosynthetic microorganisms" due to their ability to take up sunlight and split the water molecular thus converting it into chemical energy (Yilmaz et al., 2016). Water-PQOR, i.e., PSII, energizes elections in the presence of sunlight transferring them to PSI and then Fd (Eroglu and Melis, 2016); Fd-oxidoreductase produces reduced $\mathrm{Fd}$, which then donates an electron to [FeeFe]-hydrogenase enabling the reduction of the proton $(\mathrm{H}+)$ to a hydrogen molecule $\left(\mathrm{H}_{2}\right)$ and so, produces $\mathrm{O}_{2}$ at the PSI.

Fd reduction in PSI : $2 \mathrm{H}^{+}+2 \mathrm{FD}_{\text {(reduced) }} \leftrightarrow 4 \mathrm{H}_{2}+2 \mathrm{FD}_{\text {(oxidized) }}$

$\mathrm{H} 2$ production in the presence of sunlight : $2 \mathrm{H}_{2} \mathrm{O}$

$$
+ \text { light energy } \rightarrow 2 \mathrm{H}_{2}+\mathrm{O}_{2}
$$

The process of direct biophotolysis is a sustainable pathway. It has a lot of promise as the main reactants such as water, sunlight, and $\mathrm{CO}_{2}$ are commonly available products. In addition, it converts solar energy into chemical energy to produce hydrogen and oxygen (Jiménez-Llanos et al., 2020). However, the pathway still needs to overcome many challenges to become a good and feasible option for biohydrogen production. One of the major disadvantages of this pathway is the inhabitation of hydrogen production due to the accumulation of oxygen as mentioned in Table 1. Other drawbacks include the risk of using oxygen, the requirement for high light intensity, and having low photochemical efficiency (Kumar S et al., 2019). Massive cultivation of algae is required to capture enough sunlight to provide sufficient free energy $(\Delta \mathrm{G}=+237 \mathrm{~kJ}$ $\left.\mathrm{mol}^{-1}\right)$. Some other barriers include the processing and concentration of cell biomass, respiration, and photosynthetic capacity ratio (Jiménez-Llanos et al., 2020).

\section{Indirect Biophotolysis}

Indirect biophotolysis is performed by microalgae under anoxic conditions. Under these conditions, microalgae can produce biohydrogen through fermentation or respiration. The indirect method is not continuous as a return of the light period makes the growth become photosynthetic and hinders $\mathrm{H}_{2}$ ase (El-Dalatony et al., 2020). Indirect biophotolysis is a two-step process: i) the first stage involves oxygen producing and carbon dioxide fixing into chemical energy carbohydrates, and lipids; and ii) the second stage is functionally the same and a small sealed photo-bioreactor is used with $\mathrm{CO}_{2}$ synthesis which is divided periodically in the absence of light exposure (Razu et al., 2019).

Electrons released through catabolism of the endogenous subtract are used for a non-photochemical reduction on oxygen depletion which causes the initial electron transport chain to stop during the anaerobic phase. The electron is then transferred to [FeeFe]-hydrogenases resulting in biohydrogen production (Lam and Lee, 2013). This hydrogen production method using biological photolysis was first trialled on a nonheterocystous microalga such as cyanobacteria Plectonemaboryanum which was subjected to frequent cycles of "aerobic light-driven $\mathrm{CO}_{2}$ fixation and $\mathrm{O}_{2}$ " (Razu et al., 
TABLE 1 | Advantages and disadvantages of basic biohydrogen production technologies.

\begin{tabular}{|c|c|c|}
\hline Technology & Advantages & Disadvantages \\
\hline Photo fermentation & $\begin{array}{l}\text {-Photosynthetic bacteria can exploit varieties of spectral energy } \\
\text {-Process a variety of substrates } \\
\text {-Can process dark fermentation effluent } \\
\text {-Bioremediation }\end{array}$ & $\begin{array}{l}\text {-The efficiency of light conversion is lower } \\
\text {-Biohydrogen production through photosynthetic bacteria remains low } \\
\text {-Inhomogeneity of light distribution and metabolic shifting from biohydrogen } \\
\text { generation to polyhydroxybutyrate synthesis }\end{array}$ \\
\hline Dark fermentation & $\begin{array}{l}\text {-As a by-product of the process, numerous metabolites can be } \\
\text { produced and various substrates can be utilized } \\
\text {-Process a variety of substrates } \\
\text {-Light independent method } \\
\text {-No } \mathrm{O}_{2} \text { limitation issues } \\
\text {-Bioremediation }\end{array}$ & $\begin{array}{l}\text {-This technique produces a minimal amount of } \mathrm{H}_{2} \text {, making it } \\
\text { thermodynamically unfavourable } \\
\text {-Inhabitation of biohydrogen production due to the accumulation of oxygen } \\
\text {-Low biohydrogen production }\end{array}$ \\
\hline Direct biophotolysis & $\begin{array}{l}\text {-An integrated approach to producing } \mathrm{H}_{2} \text { from water and sunlight } \\
\text {-Requires simple cultivation } \\
\text {-Simple substrate of } \mathrm{H}_{2} \mathrm{O} \\
-\mathrm{CO}_{2} \text { consumption }\end{array}$ & $\begin{array}{l}\text {-High light intensity and } \mathrm{O}_{2} \text { work as an inhibitor in the process } \\
\text {-Separate high purity } \mathrm{O}_{2} \text { and } \mathrm{H}_{2} \text { streams are not attainable }\end{array}$ \\
\hline $\begin{array}{l}\text { Indirect } \\
\text { biophotolysis }\end{array}$ & $\begin{array}{l}\text {-Hydrogen generation from water using blue-green algae } \\
\text {-Separate } \mathrm{O}_{2} \text { generation from } \mathrm{H}_{2} \text { production requirement } \\
\text { - } \mathrm{N}_{2} \text { fixing capability from air } \\
\text {-Metabolite by-product conversion to } \mathrm{H}_{2}\end{array}$ & $\begin{array}{l}\text {-Hydrogenate uptake is reduced } \\
\text { - Uptake hydrogenates can be removed } \\
\text {-Hydrogenase enzyme generates carbon dioxide and provides a low yield of } \\
\text { hydrogen }\end{array}$ \\
\hline $\begin{array}{l}\text { Microbial } \\
\text { electrolysis cells }\end{array}$ & $\begin{array}{l}\text {-A pollution-free technology that produces electricity in a more } \\
\text { environmentally friendly manner } \\
\text { Bioremediation } \\
\text {-High removal of chemical oxygen demand (COD ) } \\
\text {-Can process dark fermentation effluent } \\
\text { - High recovery of } \mathrm{H}_{2} \\
\text { - High degradation of substrate }\end{array}$ & $\begin{array}{l}\text {-Solar systems can give a more efficient system, but they are more expensive } \\
\text {-Capital cost is comparatively high } \\
\text {-Hydrogen loss and purity } \\
\text {-Suffers from scalability, source of power, stability, and mode of operation }\end{array}$ \\
\hline
\end{tabular}

2019). The reactions to this process are as follows (Sharma and Arya, 2017):

$$
\begin{gathered}
12 \mathrm{H}_{2} \mathrm{O}+6 \mathrm{CO}_{2}+\text { lightenergy } \rightarrow \mathrm{C}_{6} \mathrm{H}_{12} \mathrm{O}_{6}+6 \mathrm{O}_{2} \\
\mathrm{C}_{6} \mathrm{H}_{12} \mathrm{O}_{6}+12 \mathrm{H}_{2} \mathrm{O}+\text { light energy } \rightarrow 12 \mathrm{H}_{2}+6 \mathrm{CO}_{2}
\end{gathered}
$$

To produce biohydrogen, the microalgae uses stored glycogen (Acar and Dincer, 2018a). This approach also helps to solve the oxygen sensibility issue by briefly separating oxygen and hydrogen evolution reactions coupled through $\mathrm{CO}_{2}$ fixation/ evolution. In the aerobic phase, the microalgae grow by converting light energy and fixing carbon dioxide into chemical energy such as lipids, carbohydrates, and other biomolecules (Lam et al., 2019). When there is a shortage of oxygen, the electron transport chain stops functioning. If oxygen is absent in the medium, it can create an anaerobic condition. This is why activation of oxygen-sensitive hydrogenase is necessary for producing biohydrogen from electrons produced in this pathway.

Several microalgae (oleaginous) were screened to assess their hydrogen production ability by utilizing crude glycerol as a lowcost source of exogenous carbon to develop a simultaneous hydrogen and lipid production process (Sengmee et al., 2017). All microalgae grew on crude glycerol and accumulated a high lipid content of more than $20 \%$, however only Chlorella sp. could produce a significant amount of hydrogen under the anaerobic condition. The optimum condition resulted in a maximum hydrogen generation of $11.65 \pm 0.65 \mathrm{ml} / \mathrm{L}$ in the $1 \mathrm{~L}$ bioreactor and $10.31 \pm 0.05 \mathrm{ml} / \mathrm{L}$ in the serum bottle, as well as a lipid content of more than $40 \%$ in the retrieved microalgal biomass. Exploring biohydrogen generation integrated with the production of lipid by oleaginous microalgae could make a significant contribution to the long-term viability of biofuel production using microalgae.

\section{Electrochemical Process Electrolysis}

The microbial electrolytic cell (MEC) is an alternative way of obtaining sustainable biohydrogen production from various renewable biomass energy sources by lowering the energy requirement. MECs are adaptable bioelectrochemical tools capable of converting $\mathrm{CO}_{2}$ or organic carbons into useful chemicals. The electrochemically active microalgae produce carbon dioxide and electrons that are transferred through the anode to the cathode to combine with hydrogen atoms in the solution and then releasing $\mathrm{H}+$. However, the backdrop of this electrolytic process is that it is not spontaneous and so, an external voltage supply is necessary to produce biohydrogen at the cathode of the microbial cell (Kadier et al., 2018). The use of MEC is a hybrid system that enhances the production of biohydrogen more than fermentation. Therefore, the biohydrogen production efficiency is increased in the presence of photosynthetic and non-photosynthetic microorganisms 
TABLE 2 | Microorganisms with their benefits and limitations on biohydrogen production (Razu et al., 2019).

\begin{tabular}{|c|c|c|c|c|}
\hline Microorganisms & Strains & Mode of operation & Benefits & Limitations \\
\hline Green algae & $\begin{array}{l}\text { Chlamydomonas } \\
\text { reinhardii } \\
\text { C.moewusii } \\
\text { Chlorella Vulgaris }\end{array}$ & $\begin{array}{l}\text { Direct biophotolysis } \\
2 \mathrm{H}_{2} \mathrm{O}+\text { light }+\mathrm{Fd}_{(\text {ox })} \rightarrow 4 \mathrm{H}+ \\
\mathrm{Fd}_{(\text {red })}\left(4 \mathrm{e}^{-}\right)+\mathrm{O}_{2} \\
4 \mathrm{H}^{+}+\mathrm{Fd}_{(\text {red })} \rightarrow\left(4 \mathrm{e}^{-}\right) \mathrm{Fd}_{(\text {ox })}+2 \mathrm{H}_{2} \\
\text { Photo-fermentation } \\
6 \mathrm{CO}_{2}+12 \mathrm{H}_{2} \mathrm{O} \rightarrow 6 \mathrm{O}_{2}+\mathrm{C}_{6} \mathrm{H}_{12} \mathrm{O}_{6} \\
6 \mathrm{H}_{2}+\mathrm{C}_{6} \mathrm{H}_{12} \mathrm{O}_{6} \rightarrow 12 \mathrm{H}_{2}+6 \mathrm{CO}_{2}\end{array}$ & $\begin{array}{l}\mathrm{H}_{2} \text { is produced from water and sunlight ten } \\
\text { folds more solar conversion energy is } \\
\text { produced than to trees, and crops } \\
\mathrm{CO}_{2} \text { is decreased in the environment }\end{array}$ & $\begin{array}{l}\mathrm{H}_{2} \text { production is inhibited by } \\
\text { oxygen }\end{array}$ \\
\hline Cyanobacteria & $\begin{array}{l}\text { Anabaenavariabilis } \\
\text { Cyanothece sp. } \\
\text { Synechocystis PCC } \\
6803 \\
\text { Anabaena sp. PCC7120 }\end{array}$ & $\begin{array}{l}\text { Direct biophotolysis light }+2 \mathrm{H}_{2} \mathrm{O}+ \\
\mathrm{Fd}_{(\text {ox })} \rightarrow 4 \mathrm{H}+\mathrm{Fd}_{(\text {red })}\left(4 \mathrm{e}^{-}\right)+\mathrm{O}_{2} \\
4 \mathrm{H}^{+}+\mathrm{Fd}_{(\text {(red) }}\left(4 \mathrm{e}^{-}\right) \rightarrow \mathrm{Fd}_{(\text {ox })}+2 \mathrm{H}_{2} \\
\text { Indirect biophotolysis } \\
\mathrm{N}_{2}+8 \mathrm{H}+\mathrm{Fd}_{(\text {red })}\left(8 \mathrm{e}^{-}\right)+16 \mathrm{ATP} \\
2 \mathrm{NH}_{3}+\mathrm{H}_{2}+\mathrm{Fd}(\text { ox }) \\
8 \mathrm{H}++8 \mathrm{e}+16 \mathrm{ADP}+16 \mathrm{Pi} \\
4 \mathrm{H}_{2}+16 \mathrm{ADP}+16 \mathrm{Pi} \\
12 \mathrm{H}_{2} \mathrm{O}+6 \mathrm{CO}_{2}+\mathrm{C}_{6} \mathrm{H}_{12} \mathrm{O}_{6}+6 \mathrm{O}_{2} \\
\mathrm{C}_{6} \mathrm{H}_{12} \mathrm{O}_{6}+6 \mathrm{H}_{2}+6 \mathrm{CO}_{2}+12 \mathrm{H}_{2}\end{array}$ & $\begin{array}{l}\mathrm{H}_{2} \text { is produced from water and sunlight } \\
\mathrm{CO}_{2} \text { is decreased in the environment }\end{array}$ & $\begin{array}{l}\mathrm{H}_{2} \text { is consumed by the } \\
\text { hydrogenase enzyme } \\
\mathrm{H}_{2} \text { production is inhibited by } \\
\text { oxygen }\end{array}$ \\
\hline $\begin{array}{l}\text { Photosynthetic } \\
\text { bacteria }\end{array}$ & $\begin{array}{l}\text { R. capsulatus } \\
\text { R. sulidophilus } \\
\text { Thiocapsa } \\
\text { roseopersicina }\end{array}$ & $\begin{array}{l}\text { Photo-fermentation } \\
\mathrm{CH}_{3} \mathrm{COOH}+2 \mathrm{H}_{2} \mathrm{O}+\text { light } \rightarrow \\
4 \mathrm{H}_{2}+2 \mathrm{CO}_{2} \\
\mathrm{~N}_{2}+8 \mathrm{H}^{+}+8 \mathrm{e}^{-}+16 \mathrm{ATP} \rightarrow \\
2 \mathrm{NH}_{3}+\mathrm{H}_{2}+16 \mathrm{ADP}+16 \mathrm{Pi}\end{array}$ & $\begin{array}{l}\text { Different types of waste resources like, whey, } \\
\text { distillery, and so on can be utilized } \\
\text { A wide spectrum of light can be used }\end{array}$ & $\begin{array}{l}\text { Light is required for the } \mathrm{H}_{2} \\
\text { production Fermentation causes } \\
\text { water pollution }\end{array}$ \\
\hline $\begin{array}{l}\text { Fermentative } \\
\text { bacteria }\end{array}$ & $\begin{array}{l}\text { Clostridiumbutyricum } \\
\text { Magashaeraelsdenii }\end{array}$ & $\begin{array}{l}\text { Dark fermentation } \\
\mathrm{C}_{6} \mathrm{H}_{12} \mathrm{O}_{6}+6 \mathrm{H}_{2} \mathrm{O} \rightarrow 6 \mathrm{CO}_{2}+12 \mathrm{H}_{2} \\
\text { Pyruvate }+\mathrm{CoA} \rightarrow \text { acetyl }-\mathrm{CoA}+ \\
\text { formate } \\
\text { Pyruvate }+\mathrm{CoA}+2 \mathrm{Fd}_{(\mathrm{ox})} \rightarrow \text { acetyl - } \\
\mathrm{CoA}+\mathrm{CO}_{2}+2 \mathrm{Fd}_{(\mathrm{red})}\end{array}$ & $\begin{array}{l}\mathrm{H}_{2} \text { can be produced without the presence of } \\
\text { light in anaerobic condition } \\
\text { Different carbon sources like starch, } \\
\text { cellobiose, sucrose, can be used } \\
\text { Valuable metabolites such as butyric acid, } \\
\text { lactic acid can be made }\end{array}$ & $\begin{array}{l}\text { Carbon and nitrogen sources are } \\
\text { needed for the growth } \\
\text { Fermentation causes water } \\
\text { pollution } \\
\text { Gas contained } \mathrm{CO}_{2}\end{array}$ \\
\hline
\end{tabular}

inoculated in a biomass source, such as wastewater, in an electrolytic cell.

The microorganisms that produce biohydrogen are summarized in Table 2, along with their limitations and benefits. Cyanobacteria and a collective species of green algae are proven to be great sources of alternative renewable biofuels for biogas, biodiesel, biohydrogen, and bio-oil (Khetkorn et al., 2017). Nitrogen fixation in cyanobacteria and the reduction of $\mathrm{H}+$ electrons in green algae that are generated through photosynthesis, therefore completing a bio photolysis process, is a common biohydrogen production process for these respective organisms (Park et al., 2021). Microorganisms that are either photosynthetic or non-photosynthetic and dark fermentative bacteria can produce biohydrogen.

For the production of biohydrogen, MEC systems have several advantages over traditional fermentation. For instance, fermentation processes yield $2 \mathrm{~mol}$ acetate and $4 \mathrm{~mol} \mathrm{H}_{2}$ from $1 \mathrm{~mol}$ of glucose, whereas MECs are capable of producing $12 \mathrm{~mol}$ $\mathrm{H}_{2} /$ mol glucose due to the fact that they also utilize residual organic materials (Parkash, 2016). To explore hydrogen production in the MEC using sugar industrial effluent as a substrate versus phosphate buffer catholyte, Jayabalan et al. (2020) used two graphene metal oxide nanocomposites as catalysts. At a $1.0 \mathrm{~V}$ voltage, the NiO.rGO nanocomposite demonstrated $4.38 \pm 0.11 \mathrm{mmol} / \mathrm{L} / \mathrm{D}$ as a maximum hydrogen generation rate, $20.8 \%$ cathodic hydrogen recovery and $65.6 \%$ coloumbic efficiency. The results revealed that the MEC system can contribute to a 2.68- and 1.19-times higher efficiency in biohydrogen production than uncoated Ni-Foam and $\mathrm{Co}_{3} \mathrm{O}_{4} \cdot \mathrm{rGO}$, respectively. However, energy recovery via industrial effluents, combined with technological improvements and simultaneous treatment, must be further improved for the long-term sustainability of biohydrogen production using this method.

\section{Photoelectrochemical}

The microbial photoelectrochemical cell (PEC) is a cuttingedge technology that generates sustainable biohydrogen from organic waste using light-aided synergistic microbial conversion. In the PEC, electrons are synthesized electrochemically from organic compounds on the microbial- or bio-anode by active microorganisms. The PEC 
TABLE 3 | Overview of biohydrogen production technologies from microalgae.

\begin{tabular}{|c|c|c|c|c|c|c|}
\hline Technology & Basic principle & Microorganism & Yield of $\mathrm{H}_{2}$ & Efficiency & Conditions & References \\
\hline \multirow[t]{3}{*}{$\begin{array}{l}\text { Photo } \\
\text { fermentation }\end{array}$} & $\begin{array}{l}\text { In the presence of light, } \\
\text { photosynthetic bacteria } \\
\text { convert complex organic } \\
\text { microalgal biomass into } \\
\text { simpler organic or } \\
\text { inorganic components }\end{array}$ & $\begin{array}{l}\text { Photoheterotrophic } \\
\text { bacteria } \\
\text { (Rhodopseudomona, } \\
\text { Rhodobacter) }\end{array}$ & $\begin{array}{l}\text { Maximum } 160.40 \pm \\
2.70 \mathrm{ml} / \mathrm{gCS}\end{array}$ & $\begin{array}{l}15.93 \% \text { efficiency in } \\
\text { energy conversion }\end{array}$ & $\begin{array}{l}\text { Biohydrogen } \\
\text { production, as well as } \\
\text { energy conversion } \\
\text { efficiency, can be } \\
\text { enhanced from corn } \\
\text { stalk }\end{array}$ & Lu et al. (2021) \\
\hline & & $\begin{array}{l}\text { (Rhodospirillum and } \\
\text { Rhodobium) }\end{array}$ & $\begin{array}{l}36.08-141.42 \mathrm{ml} \\
(\mathrm{g} \mathrm{TS})^{-1}\end{array}$ & $\begin{array}{l}10.12 \% \text { efficiency in } \\
\text { energy conversion }\end{array}$ & $\begin{array}{l}\text { Promising technology } \\
\text { for the production of } \\
\text { biohydrogen from } \\
\text { corn stover }\end{array}$ & Zhang et al. (2020) \\
\hline & & & $\begin{array}{l}<59 \% \text { depending on } \\
\text { the microbes cellulose } \\
\text { structure }\end{array}$ & $\begin{array}{l}10 \% \text { efficiency in } \\
\text { energy conversion }\end{array}$ & $\begin{array}{l}\text {-Substrate conversion } \\
\text { efficiency } \\
\text {-Optimum light } \\
\text { penetration } \\
\text { - Use of Oxygen } \\
\text { absorbers }\end{array}$ & $\begin{array}{l}\text { El-Dalatony et al. } \\
\text { (2020), Jim and } \\
\text { Ramı, (2020), and } \\
\text { Mona et al. (2020) }\end{array}$ \\
\hline \multirow[t]{3}{*}{$\begin{array}{l}\text { Dark } \\
\text { fermentation }\end{array}$} & $\begin{array}{l}\text { In the absence of light, } \\
\text { complex organic } \\
\text { microalgal biomass is } \\
\text { converted into simpler } \\
\text { organic or inorganic } \\
\text { components. }\end{array}$ & $\begin{array}{l}\text { Fermentative bacteria } \\
\text { (Escherichia coli, } \\
\text { Clostridia, Enterobacter) }\end{array}$ & $89.80 \mathrm{ml} / \mathrm{gVS}$ & $\begin{array}{l}42.80 \% \\
\text { improvement }\end{array}$ & $\begin{array}{l}\text { Further optimization } \\
\text { can significantly } \\
\text { increase the rate of } \\
\text { biohydrogen } \\
\text { production from } 1.42 \\
\text { to } 4.64 \mathrm{ml} / \mathrm{gVS} / \mathrm{h}\end{array}$ & Song et al. (2020) \\
\hline & & Alcaligenes, Citrobacter & $\begin{array}{l}36.08-141.42 \mathrm{ml} \cdot(\mathrm{g} \\
\mathrm{TS})^{-1}\end{array}$ & $\begin{array}{l}2.58 \% \text { efficiency in } \\
\text { energy conversion }\end{array}$ & $\begin{array}{l}\text { Effective production of } \\
\text { biohydrogen from } \\
\text { corn stover }\end{array}$ & Zhang et al. (2020) \\
\hline & & (Bacillus) & Approximately $19.30 \%$ & & $\begin{array}{l}\text { A very efficient } \\
\text { hydrogen isolation } \\
\text { technique is required }\end{array}$ & $\begin{array}{l}\text { El-Dalatony et al. } \\
\text { (2020), Jim and } \\
\text { Ramı, (2020), Mona } \\
\text { et al. (2020), and } \\
\text { Lee, (2021) }\end{array}$ \\
\hline $\begin{array}{l}\text { Direct } \\
\text { biophotolysis }\end{array}$ & $\begin{array}{l}\text { In the presence of a direct } \\
\text { light source, pigment- } \\
\text { containing } \\
\text { microorganisms are used } \\
\text { in a sequence of } \\
\text { processes to generate } \\
\text { hydrogen from water } \\
\text { molecules }\end{array}$ & $\begin{array}{l}\text { Cyanobacteria } \\
\text { Green algae }\end{array}$ & Greater than $10 \%$ & More than $80 \%$ & $\begin{array}{l}\text {-Availability of } \\
\text { ferredoxin } \\
\text {-High ATP, NADPH } \\
\text { contents } \\
\text {-Utilization of } \mathrm{O}_{2} \\
\text { absorber } \\
\text {-Nitrogenase } \\
\text { inactivation }\end{array}$ & $\begin{array}{l}\text { Mona et al. (2020), } \\
\text { El-Dalatony et al. } \\
\text { (2020), Jim and } \\
\text { Ramı, (2020), Kant } \\
\text { et al. (2021), Mona } \\
\text { et al. (2020), and } \\
\text { Razu et al. (2019) }\end{array}$ \\
\hline \multirow[t]{2}{*}{$\begin{array}{c}\text { Indirect } \\
\text { biophotolysis }\end{array}$} & $\begin{array}{l}\text { In PS I and PS II } \\
\text { compartments, sulphur- } \\
\text { deficient microorganisms } \\
\text { are used in one or more } \\
\text { step reactions to generate }\end{array}$ & Cyanobacteria & $\begin{array}{l}\text { Approximately } \\
10-15 \%\end{array}$ & $\begin{array}{l}16.30 \% \text { efficiency in } \\
\text { light conversion }\end{array}$ & $\begin{array}{l}\text {-Increased efficiency } \\
\text { in light conversion } \\
\text {-Hydrogenase } \\
\text { inactivation }\end{array}$ & $\begin{array}{l}\text { El-Dalatony et al. } \\
\text { (2020), Jim and } \\
\text { Ramı, (2020), Kant } \\
\text { et al. (2021), and } \\
\text { Mona et al. (2020) }\end{array}$ \\
\hline & $\begin{array}{l}\text { hydrogen from complex } \\
\text { carbohydrates or pyruvate }\end{array}$ & & 6.40 times more & & $\begin{array}{l}\text { Biomass yield can be } \\
\text { improved } 7.30 \text { times } \\
\text { more by a two-stage } \\
\text { biophotolysis system } \\
\text { compared to a single- } \\
\text { stage system }\end{array}$ & $\begin{array}{l}\text { Rather and } \\
\text { Srivastav, (2021) }\end{array}$ \\
\hline $\begin{array}{l}\text { Microbial } \\
\text { fuel cells }\end{array}$ & $\begin{array}{l}\text { The bioelectrochemical } \\
\text { approach produces an } \\
\text { electric current by } \\
\text { decomposing } \\
\text { microorganisms }\end{array}$ & $\begin{array}{l}\text { Electrochemically active } \\
\text { bacteria (Aeromonas } \\
\text { hydrophila, Shewanella } \\
\text { putrefaciens) }\end{array}$ & Approximately 90\% & $\begin{array}{l}60-78 \% \text { conversion } \\
\text { efficiency }\end{array}$ & $\begin{array}{l}\text {-Pressure, } \\
\text { temperature, and the } \\
\text { sorts of electrodes } \\
\text { used should all be } \\
\text { selected carefully } \\
\text { - Integrating with other } \\
\text { techniques ensures } \\
\text { performance } \\
\text { enhancement }\end{array}$ & $\begin{array}{l}\text { Azwar et al. (2014), } \\
\text { Kumar et al. (2017), } \\
\text { El-Dalatony et al. } \\
\text { (2020), and Fadakar } \\
\text { et al. (2020) }\end{array}$ \\
\hline
\end{tabular}


TABLE 3 | (Continued) Overview of biohydrogen production technologies from microalgae.

\begin{tabular}{|c|c|c|c|c|c|c|}
\hline Technology & Basic principle & Microorganism & Yield of $\mathbf{H}_{2}$ & Efficiency & Conditions & References \\
\hline \multirow[t]{2}{*}{$\begin{array}{l}\text { Microbial } \\
\text { electrolysis } \\
\text { cells }\end{array}$} & $\begin{array}{l}\text { The bioelectrochemical } \\
\text { method that decomposes } \\
\text { bacteria by using } \\
\text { electricity }\end{array}$ & $\begin{array}{l}\text { Exoelectrogenic bacteria } \\
\text { such as Geobacteraceae }\end{array}$ & $4.38 \pm 0.11 \mathrm{mmol} / \mathrm{L} / \mathrm{D}$ & $\begin{array}{l}2.68 \text { and } 1.19 \text {-times } \\
\text { higher efficiency in } \\
\text { biohydrogen } \\
\text { production than } \\
\text { uncoated Ni-Foam } \\
\text { and } \mathrm{Co}_{3} \mathrm{O}_{4} \cdot \mathrm{rGO} \text {, } \\
\text { respectively }\end{array}$ & $\begin{array}{l}\text { Energy recovery via } \\
\text { industrial effluents, } \\
\text { combined with } \\
\text { technological } \\
\text { improvements and } \\
\text { simultaneous } \\
\text { treatment, must be } \\
\text { emphasized for long- } \\
\text { term sustainability }\end{array}$ & $\begin{array}{l}\text { Jayabalan et al. } \\
\text { (2020) }\end{array}$ \\
\hline & & & Approximately 90\% & & $\begin{array}{l}\text {-Pressure, } \\
\text { temperature, and the } \\
\text { sorts of electrodes } \\
\text { used should all be } \\
\text { selected carefully } \\
\text {-Expenditure is } \\
\text { contingent upon the } \\
\text { cost of external power }\end{array}$ & $\begin{array}{l}\text { Azwar et al. (2014), } \\
\text { Kumar et al. (2017), } \\
\text { El-Dalatony et al. } \\
\text { (2020), and Fadakar } \\
\text { et al. (2020) }\end{array}$ \\
\hline
\end{tabular}

consists of semiconductors (electrodes) that are separated by a membrane in an electrolyte. Semiconductors and sunlight are utilized directly in the photoelectrochemical process to separate water into hydrogen and oxygen. During the photoelectrochemical process, water molecules oxidize resulting in oxygen production and biohydrogen reduction as the $\mathrm{H}_{2}$ production occurs in the opposite electrode (ElDalatony et al., 2020). This method has a high potential for biohydrogen production with minimal environmental effects.

Few investigations have been conducted on solar microbial photoelectrochemical systems on the basis of photobioanodes, in which bio and solar energy are integrated at the same electrode. Utilising a photo-bioanode with two sides, biocarbon material and photocatalyst $\left(\mathrm{a}-\mathrm{Fe}_{2} \mathrm{O}_{3}\right)$, researchers expedited biofilm formation, improved extracellular electron transport, and enriched exoelectrogens (Feng et al., 2016). The metal-free carbon film based on $\mathrm{CeO}_{2}-\mathrm{rGO}$ was recently employed as a photo-bioanode, with the suggested system achieving a hydrogen evolution rate of $5 \mathrm{~m}^{3} / \mathrm{m}^{3} / \mathrm{d}$ while simultaneously treating the wastewater (Pophali et al., 2020). Zhu et al. (2017) demonstrated that output power and photocurrents are increased at visible light using a hematite nanowirearrayed photoanode and designed exoelectrogens. However, this technique necessitates more research to attain a sustainable level of biohydrogen production. Table 3 provides an overview of commonly available technologies of biohydrogen production from microalgae.

\section{ECONOMIC ANALYSIS OF BIOHYDROGEN PRODUCTION}

Even though biohydrogen production has increasingly exhibited promising results at the pilot and laboratory scale, studies focused on optimization of process parameters and the feasibility of scaling up to the industrial level are largely absent (Oncel,
2015). Unlike the chemical synthesis of hydrogen, biohydrogen production has many challenges. Solving the technical and engineering problems may cost approximately $\$ 1.42$ million (El-Dalatony et al., 2020). Thus, even though $1 \mathrm{~kg}$ of hydrogen is equivalent to $3.79 \mathrm{~kg}$ gasoline (Show et al., 2018), for hydrogen to be competitive with an energy price of gasoline $\left(\$ 2.50 \mathrm{GJ}^{-1}\right)$, the commercial goal for hydrogen production cost needs to be $\$ 0.30 \mathrm{~kg}^{-1}$ (Goswami et al., 2021).

The microalgae cultivation system and reactor design primarily determine the production cost of biohydrogen. For instance, when biohydrogen is produced from a biophotolysis system, cultivation in a 140 ha open pond and 14 ha photobioreactor can cost $\$ 6 \mathrm{~m}^{-2}$ and $\$ 100 \mathrm{~m}^{-2}$, respectively, with a $\$ 43$ million capital cost and $\$ 10$ million annual operational costs, leading to a production cost of $\$ 10 \mathrm{GJ}^{-1}$ (Mona et al., 2020). The capital investment was almost $90 \%$ of the total cost with the capital charge calculated at $25 \%$ annually. Operating at $90 \%$ capacity, the system aims to produce $1200 \mathrm{TJ}$ of biohydrogen per year (Mona et al., 2020). However, the hydrogen handling and storage costs were not factored in the total calculation, even though these are significant cost factors that can amount to about $\$ 0.58$ million (El-Dalatony et al., 2020).

Following the initial failure of continuous biohydrogen production using S-deprived wild type $C$. reinhardtii, the National Renewable Energy Laboratory in collaboration with the researchers at UC-Berkeley developed a two-stage continuous phase system that promoted an aerobic growth phase and a subsequent anaerobic hydrogen evolving phase (Nagarajan et al., 2021). Their design reduced the photobioreactor costs to $\$ 1 \mathrm{~m}^{-2}$, determined the selling price of hydrogen at $\$ 8.97 \mathrm{~kg}^{-1}$ (or $\$ 22.80 \mathrm{kWh}^{-1}$ ), and further revealed the capital costs of custom-built photobioreactors can be drastically reduced if open ponds are used. Their first design used a photobioreactor costing $\$ 10 \mathrm{~m}^{-2}$ and considered utilization of pressure swing adsorption for hydrogen purification and the compression of biohydrogen to $20 \mathrm{MPa}$ for transporting and storing at a facility with the capacity of 
$300 \mathrm{~kg} /$ day. Changes in the flow in accordance with requirements led to production costs of between $\$ 0.57 \mathrm{~kg}^{-1}$ and $13.53 \mathrm{~kg}^{-1}$ which was deemed feasible. However, the production stopped 4 days after sulphur deprivation.

Gholkar et al. (2021) conducted a techno-economic feasibility study of a plant in India that cultivated microalgae in an open pond at the rate of $12,790 \mathrm{kgh}^{-1}$ and produced $1,239 \mathrm{~kg}$ of biohydrogen per hour. The total capital investment was estimated at $\$ 144.6$ million, $11 \%$ of which was used to purchase the gasifier and its accessories. In addition, $76 \%$ of the total operating cost, which was $\$ 7,692$ per year was attributed to the cultivation of microalgae, while the remaining was spent on utilities. Having assumed a market price of $\$ 10 \mathrm{~kg}^{-1}$, they concluded that biohydrogen production was economically feasible, with a payback period of 3.78 years and an internal rate of return of $22 \%$. Because profitability was primarily determined by the biohydrogen composition and the cost of microalgae production, the researchers recommended developing and using highly selective catalysts.

James et al. (2009) attempted to estimate the production cost of biohydrogen using oxygen tolerant microalgae and found a cost of $\$ 1.38 \mathrm{~kg}^{-1}$, excluding the cost for storage (Jiménez-Llanos et al., 2020). $42 \%$ of the cost was derived from photobioreactor operation, $34 \%$ from the resources required for the biohydrogen collection, and $13 \%$ from recycling and pumping systems. Moreover, $4 \%$ of the costs were required for the microalgae feed assembly, with the remaining costs attributable to other control systems and consumables. Storage is an important cost consideration as it serves as a major limitation. To make the production price affordable for direct biophotolysis, it was recommended that the conversion efficiency and biomass production be raised to 13.4 and $9.4 \%$, respectively. Another study (Melis and Happe, 2001), which assumes biohydrogen is produced $100 \%$ by photosynthesis, found that with a plant running at half capacity and an estimated production rate of $80 \mathrm{~kg}$ biohydrogen acre ${ }^{-1} \mathrm{day}^{-1}$, biohydrogen would cost about $\$ 2.80 \mathrm{~kg}^{-1}$ which can be competitive with gasoline (JiménezLlanos et al., 2020).

Some bioreactor designs can also significantly raise the production cost, particularly depending on the manufacturing materials (Sathyaprakasan and Kannan, 2015), because the cost of materials and nutrients can make up more than $80 \%$ of major expenses (Show et al., 2018). A near-horizontal tubular reactor system built using single-stage algal biophotolysis cost $\$ 50 \mathrm{~m}^{-2}$, assuming a $17 \%$ capital charge per year and a $10 \%$ efficiency of sunlight conversion. This led to an overall biohydrogen production cost of $\$ 15 \mathrm{GJ}^{-1}$. An assessment of a simplified design of a pilot modular photoreactor for 6 months' field operation not only provided overall comparative costs of different technology compartments but also established a construction cost of $\$ 0.75 \mathrm{~m}^{-2}$, which was significantly lower than frequently reported costs of $\$ 20-\$ 100 \mathrm{~m}^{-2}$. The study revealed that chemical nutrients and fabrication materials represented $84 \%$ of the main expenditure.

A techno-economic evaluation of a system producing biohydrogen through supercritical and thermal gasification of microalgae biomass suggested that generating 2,000 dry tonnes of biohydrogen per day required a total capital investment of $\$ 215.3$ million and $\$ 277.8$ million for thermal and supercritical gasification, respectively, to yield biohydrogen with a product value of $\$ 4.59$ and $\$ 5.66 \mathrm{~kg}^{-1}$, respectively (Kumar M et al., 2019). The total capital cost comprised individually purchased equipment, installation, and indirect costs, such as construction, engineering, and contingencies. For thermal gasification, the installed capital cost was $\$ 131.48$ million whereas it was $\$ 169.6$ million for supercritical gasification. The construction of the thermochemical plant was considered to occupy 20,35, and $45 \%$ of the total capital cost for the first, second, and third years, respectively. Maintenance made up 3\% of the total project investment, while labour cost was assumed to be $25 \%$ of the total operating cost. Plant overheads comprised half of the total labour and maintenance costs. General and administrative expenses were assumed to be $8 \%$ of the operating cost. Overall, the production cost of biohydrogen was reported to be fourfold the cost of hydrogen from natural gas.

The efficient microalgal biohydrogen production is hindered by numerous process parameters that affect the progress of metabolic activities. For instance, light intensity or the accessibility to radiation energy alone can significantly affect biohydrogen synthesis (Oey et al., 2016). In particular, in the artificial environment, the different light intensities reduce the efficiency of the metabolic capacity of microalgae, which is often not an issue in natural habitats where algae can adapt based on needs. Consequently, proper mixing of microalgal culture is crucial for effective light capture. Light can be either an inhibiting factor or a limiting factor depending on the metabolic route utilized for biohydrogen production. Furthermore, $\mathrm{pH}$ is also an important physical factor that influences biohydrogen production using microalgae (Razu et al., 2019). Even though the appropriate $\mathrm{pH}$ depends on the microalgae species in use, minimal changes in the $\mathrm{pH}$ can significantly affect the hydrogen-producing enzyme as well as the growth and metabolic activity of microalgae, affecting their biohydrogen production capacity.

Temperature is another physical parameter that affects biomass productivity and the biohydrogen production capacity within a medium. The optimum temperature for the sustainable proliferation of microalgae and the maximum biohydrogen production has been reported to be $15-85^{\circ} \mathrm{C}$ in a mixed culture (Razu et al., 2019). The availability of essential micro and macronutrients for enhanced biomass productivity also affects cost. Furthermore, the availability of these nutrients may initiate a stress response within the microalgal cells, which may be exploited to produce different kinds of biofuels. Biohydrogen has been reported to be generated when microalgae are subjected to sulphur (Gonzalez-Ballester et al., 2015), nitrogen (Nagarajan et al., 2017), phosphorous (Batyrova et al., 2015), magnesium (Volgusheva et al., 2015), and potassium deprivation. 
The presence of an organic carbon source is also important for cultivation, except for phototrophic strains. The processes involved with microalgal biomass-led biohydrogen production face additional challenges for the smooth and sustainable production of biohydrogen. Oxygen sensitivity is regarded as one of the most challenging obstacles to overcome for many biohydrogen production technologies. The high binding potential of oxygen to the active sites of hydrogenase (El-Dalatony et al., 2020) create irreversible bonds that make it difficult to extract hydrogen and oxygen molecules from the complex compound (Eroglu and Melis, 2016). In addition, issues like altered thylakoid proton gradient, light capture disruption, and low efficiency of photosynthetic activities also contribute to high production costs.

Finally, there are significant differences in the costs of biohydrogen production depending on the routes discussed in the previous section. For instance, utilizing direct biophotolysis for biohydrogen costs an estimated $\$ 2.80 \mathrm{~kg}^{-1}$ and generated $20 \mathrm{~kg}$ per $1,000 \mathrm{~m}^{-2}$ day $^{-1}$ (Show et al., 2018). Resnick (2004), undertook comprehensive calculations of the production costs of each of the metabolic pathways. He estimated that direct biophotolysis, with a capital cost of $\$ 1220 \mathrm{GJ}^{-1}$ year $^{-1}$ calculated at $\$ 2.47 \mathrm{~m}^{-2}$ and an operating cost of over $\$ 70,000$ million broken down by power (\$2.49 million), water ( $\$ 0.02$ million), labour ( $\$ 50.4$ billion), supplies ( $\$ 7.75$ billion), culture production ( $\$ 5.8$ billion), gas separation and handling ( $\$ 23$ million), and a subtotal operating cost ( $>\$ 63,900$ million) with a contingency of $10 \%$, resulted in a biohydrogen production cost of $\$ 11,170.33 \mathrm{GJ}^{-1}$. Biohydrogen produced from indirect biophotolysis with a capital cost of approximately $2.40 \mathrm{GJ}^{-1}$ year $^{-1}$ and an operating cost of about $\$ 102.1$ million on an annualized basis had a production cost of $\$ 16.26 \mathrm{GJ}^{-1}$ (Ghosh et al., 2017). The complete breakdown of the operating cost is as follows: power ( $\$ 2.5$ million), water $(\$ 0.02$ million), labour ( $\$ 65$ million), supplies (\$17.3 million), culture production ( $\$ 8.2$ million), gas separation and handling (\$0.09 million), and subtotal operating costs (about $\$ 93$ million) with a contingency of 10\% (Resnick, 2004).

Another study (Hallenbeck and Benemann, 2002) reported that biohydrogen using direct biophotolysis assuming an optimistic capital cost of $\$ 50 \mathrm{~m}^{-2}$ maintained a production cost of $\$ 2.13 \mathrm{~kg}^{-1}$ (Nikolaidis and Poullikkas, 2017; Acar and Dincer, 2018a). This implies that a $20 \%$ increase in capital cost would raise the production cost by $33 \%$. However, the calculations considered minimal operating costs, at an overall solar conversion efficiency of $10 \%$, and did not account for many significant cost components such as engineering, gas separation and handling. On the other hand, the capital cost using indirect biophotolysis was $\$ 135 \mathrm{~m}^{-2}$ and the production cost was $\$ 1.42 \mathrm{~kg}^{-1}$ (Nikolaidis and Poullikkas, 2017). Dincer and Acar (2015) illustrated that direct biophotolysis yielded biohydrogen at a cost of $\$ 7.27 \mathrm{~kg}^{-1}$, whereas photofermentation and dark fermentation cost $\$ 7.61 \mathrm{~kg}^{-1}$ and $\$ 7.52 \mathrm{~kg}^{-1}$, respectively.

Resnick (2004) calculated a production cost of $\$ 30.7 \mathrm{GJ}^{-1}$ using photofermentation. An operating cost of over \$193 million was assumed, incorporating the costs for power $(\$ 2.5$ million), water ( $\$ 0.01$ million), labour ( $\$ 23$ million), supplies (\$3.5 million), culture production ( $\$ 2.7$ million), gas separation and handling (\$0.13 million), and a subtotal operating cost
(> \$175 million) with a contingency of $10 \%$. The Tredeci-style reactor serves as a significant cost-driver, resulting in a capital cost of $\$ 1.41 \mathrm{GJ}^{-1}$ year $^{-1}$. Dark fermentation, on the other hand, was found to produce biohydrogen at a cost of $\$ 155.59 \mathrm{GJ}^{-1}$. Dark fermentation has potentially the lowest capital cost of about $\$ 0.64 \mathrm{GJ}^{-1}$ year $^{-1}$ (Resnick, 2004), attributed to the small footprint of the bioreactor. The operating cost of over $\$ 980$ million can be broken down into power ( $\$ 2.5$ million), water (\$0.02 million), labour ( $\$ 17.8$ million), supplies (\$2.7 million), culture production ( $\$ 2$ million), gas separation and handling ( $\$ 0.6$ million), and a subtotal operating cost (about $\$ 891$ million) with a contingency of $10 \%$.

Overall, photofermentation exhibits a higher yield but is relatively expensive (Bolatkhan et al., 2019). Others have demonstrated that photovoltaic processes are more expensive than direct biophotolysis (Goswami et al., 2021), costing up to $\$ 170 \mathrm{~m}^{-3}$ whereas the latter resulted in a cost of $\$ 25 \mathrm{~m}^{-3}$. Many of recent studies (Eroglu and Melis, 2016; Khetkorn et al., 2017; Anwar et al., 2019; El-Dalatony et al., 2020; Peng et al., 2020; Singh and Das, 2020; Goswami et al., 2021; Limongi et al., 2021; Wang et al., 2021) primarily extol the advantages of synthetic biology, as advancements in molecular and genetic engineering have allowed these options to be explored for improving the strains of algae to optimize biohydrogen yields. This is no surprise, as synthetic biological methods have a higher yield and output compared to the metabolic routes discussed (Goswami et al., 2021). In general, however, biohydrogen production tends to be more expensive than other fuel alternatives (Show et al., 2018). Nevertheless, the economic analyses of biohydrogen production have been scanty, especially for electrochemical processes.

Most of the economic studies were conducted between 10 and 20 years ago, making economic feasibility analysis of biohydrogen production using state-of-art technology ambiguous. Moreover, many of the existing studies on the economics of biohydrogen are substantially optimistic. It has been calculated that biohydrogen can be produced at a cost between $\$ 10-20 \mathrm{GJ}^{-1}$ (Show et al., 2019b). Regardless, such production costs are too high for biohydrogen to serve as a competitive alternative to gasoline, which costs $\$ 0.33 \mathrm{GJ}^{-1}$. Future work needs to be directed towards comprehensive evaluations with regards to facility feasibility and operation, material and operation costs, light, weather, and land requirements, the mixing of biomass, and stability. Economic feasibility can be improved by recycling residual metabolites and biomass.

\section{CONCLUSION}

Different techniques for biohydrogen production offer diverse benefits, even though none are currently feasible for large-scale implementation. The fermentation processes are more eco-friendly, however they have low efficiency in sunlight conversion and biohydrogen yield. Biophotolysis methods also have a low biohydrogen yield $(<15 \%)$ and face several challenges in terms of oxygen sensitivity and the availability of sunlight. Nevertheless, direct biophotolysis offers an efficiency of more than $80 \%$. The 
electrochemical processes are found to be significantly energyintensive, with high requirements of pressure, temperature, power, and sophisticated equipment, but yield 90\% biohydrogen. The current production cost of biohydrogen is quite high, ranging between $\$ 10-\$ 20 \mathrm{GJ}^{-1}$, depending on the microalgae cultivation system, reactor design, and the metabolic route used. In order to compete with gasoline, this cost must be less than $\$ 0.33 \mathrm{GJ}^{-1}$. On the other hand, most economic assessments are fairly optimistic but fail to account for important cost factors such as storage, handling, and transportation. There is also a gap in current economic evaluations as most studies were conducted decades ago. Thus, future research should be directed towards properly assessing the economic feasibility of biohydrogen production processes in order to scale up the technology.

\section{REFERENCES}

Abdalla, A. M., Hossain, S., Nisfindy, O. B., Azad, A. T., Dawood, M., and Azad, A. K. (2018). Hydrogen Production, Storage, Transportation and Key Challenges with Applications: A Review. Energ. Convers. Manage. 165, 602-627. doi:10.1016/j.enconman.2018.03.088

Acar, C., and Dincer, I. (2018a). 3.1 Hydrogen Production. Compr. Energ. Syst 3, 1-40. doi:10.1016/b978-0-12-809597-3.00304-7

Ahmed, S. F., Mofijur, M., Parisa, T. A., Islam, N., Kusumo, F., Inayat, A., et al. (2021b). Progress and Challenges of Contaminate Removal from Wastewater Using Microalgae Biomass. Chemosphere 286, 131656. doi:10.1016/ j.chemosphere.2021.131656

Ahmed, S. F., Liu, G., Mofijur, M., Azad, A. K., Hazrat, M. A., and Chu, Y.-M. (2021a). Physical and Hybrid Modelling Techniques for Earth-Air Heat Exchangers in Reducing Building Energy Consumption: Performance, Applications, Progress, and Challenges. Solar Energy 216, 274-294. doi:10.1016/j.solener.2021.01.022

Anwar, M., Lou, S., Chen, L., Li, H., and Hu, Z. (2019). Recent Advancement and Strategy on Bio-Hydrogen Production from Photosynthetic Microalgae. Bioresour. Tech. 292, 121972. doi:10.1016/j.biortech.2019.121972

Azwar, M. Y., Hussain, M. A., and Abdul-Wahab, A. K. (2014). Development of Biohydrogen Production by Photobiological, Fermentation and Electrochemical Processes: A Review. Renew. Sust. Energ. Rev. 31, 158-173. doi:10.1016/j.rser.2013.11.022

Baeyens, J., Zhang, H., Nie, J., Appels, L., Dewil, R., Ansart, R., et al. (2020). Reviewing the Potential of Bio-Hydrogen Production by Fermentation. Renew. Sust. Energ. Rev. 131, 110023. doi:10.1016/j.rser.2020.110023

Batyrova, K., Gavrisheva, A., Ivanova, E., Liu, J., and Tsygankov, A. (2015). Sustainable Hydrogen Photoproduction by Phosphorus-Deprived marine green Microalgae Chlorella Sp. Ijms 16, 2705-2716. doi:10.3390/ijms16022705

Bolatkhan, K., Kossalbayev, B. D., Zayadan, B. K., Tomo, T., Veziroglu, T. N., and Allakhverdiev, S. I. (2019). Hydrogen Production from Phototrophic Microorganisms: Reality and Perspectives. Int. J. Hydrogen Energ. 44, 5799-5811. doi:10.1016/j.ijhydene.2019.01.092

Buitrón, G., Carrillo-Reyes, J., Morales, M., Faraloni, C., and Torzillo, G. (2017). Biohydrogen Production from Microalgae. Feed. Cultiv. End-products, 209-234. Microalgae-Based Biofuels Bioprod. doi:10.1016/B978-0-08-101023-5.00009-1

Dalena, F., Senatore, A., Tursi, A., and Basile, A. (2017). Bioenergy Production from Second- and Third-Generation Feedstocks. Bioenergy Syst. Future, 559-599. Elsevier Ltd. doi:10.1016/b978-0-08-101031-0.00017-x

Das, D., Khanna, N., and Dasgupta, C. N. (2019). Biohydrogen Production: Fundamentals and Technology Advances. Boca Raton: CRC Press.

Dawood, F., Anda, M., and Shafiullah, G. M. (2020). Hydrogen Production for Energy: An Overview. Int. J. Hydrogen Energ. 45, 3847-3869. doi:10.1016/ j.ijhydene.2019.12.059

Dincer, I., and Acar, C. (2015). Review and Evaluation of Hydrogen Production Methods for Better Sustainability. Int. J. Hydrogen Energ. 40, 11094-11111. doi:10.1016/j.ijhydene.2014.12.035

\section{AUTHOR CONTRIBUTIONS}

SA: Original draft, NR: Original draft, MM: Supervision, Reviewediting, IB: Funding acquisition, Review-editing, AI: Review and editing, MA: Resources, Software, Review, OF: Review and editing, TK: Funding acquisition, Review.

\section{ACKNOWLEDGMENTS}

The authors extend their appreciation to the Deanship of Scientific Research at King Khalid University for funding this work through research groups program under grant number (RGP. 1/101/42).

El-Dalatony, M. M., Zheng, Y., Ji, M.-K., Li, X., and Salama, E.-S. (2020). Metabolic Pathways for Microalgal Biohydrogen Production: Current Progress and Future Prospectives. Bioresour. Tech. 318, 124253. doi:10.1016/j.biortech.2020.124253

Eroglu, E., and Melis, A. (2016). Microalgal Hydrogen Production Research. Int. J. Hydrogen Energ. 41, 12772-12798. doi:10.1016/j.ijhydene.2016.05.115

Fadakar, A., Mardanpour, M. M., and Yaghmaei, S. (2020). The Coupled Microfluidic Microbial Electrochemical Cell as a Self-Powered Biohydrogen Generator. J. Power Sourc. 451, 227817. doi:10.1016/j.jpowsour.2020.227817

Feng, H., Liang, Y., Guo, K., Li, N., Shen, D., Cong, Y., et al. (2016). Hybridization of Photoanode and Bioanode to Enhance the Current Production of Bioelectrochemical Systems. Water Res. 102, 428-435. doi:10.1016/j.watres.2016.06.061

Foong, S. Y., Chan, Y. H., Cheah, W. Y., Kamaludin, N. H., Tengku Ibrahim, T. N. B., Sonne, C., et al. (2020). Progress in Waste Valorization Using Advanced Pyrolysis Techniques for Hydrogen and Gaseous Fuel Production. Bioresour. Technol. 320, 124299. doi:10.1016/j.biortech.2020.124299

Ge, S., Foong, S. Y., Ma, N. L., Liew, R. K., Wan Mahari, W. A., Xia, C., et al. (2020). Vacuum Pyrolysis Incorporating Microwave Heating and Base Mixture Modification: an Integrated Approach to Transform Biowaste into EcoFriendly Bioenergy Products. Renew. Sust. Energ. Rev. 127, 109871. doi:10.1016/j.rser.2020.109871

Gholkar, P., Shastri, Y., and Tanksale, A. (2021). Renewable Hydrogen and Methane Production from Microalgae: A Techno-Economic and Life Cycle Assessment Study. J. Clean. Prod. 279, 123726. doi:10.1016/j.jclepro.2020.123726

Ghosh, R., Bhadury, P., and Debnath, M. (2017). "Characterization and Screening of Algal Strains for Sustainable Biohydrogen Production: Primary Constraints," in Biohydrogen Production: Sustainability of Current Technology and Future Perspective. Editors A. Singh and D. Rathore (Springer), 115-146. doi:10.1007/ 978-81-322-3577-4_6

Gielen, D. (2019). Hydrogen: A Renewable Energy Perspective. Irena. Abu Dhabi.

Gonzalez-Ballester, D., Jurado-Oller, J. L., and Fernandez, E. (2015). Relevance of Nutrient media Composition for Hydrogen Production in Chlamydomonas. Photosynth. Res. 125, 395-406. doi:10.1007/s11120-015-0152-7

Goswami, R. K., Mehariya, S., Obulisamy, P. K., and Verma, P. (2021). Advanced Microalgae-Based Renewable Biohydrogen Production Systems: A Review. Bioresour. Tech. 320, 124301. doi:10.1016/j.biortech.2020.124301

Hallenbeck, P., and Benemann, J. R. (2002). Biological Hydrogen Production; Fundamentals and Limiting Processes. Int. J. Hydrogen Energ. 27, 1185-1193. doi:10.1016/s0360-3199(02)00131-3

James, B. D., Baum, G. N., Perez, J., and Baum, K. N. (2009). Technoeconomic Boundary Analysis of Biological Pathways to Hydrogen Production, 1-193. DOE Contract Number SR-560-46674 22201.

Jayabalan, T., Matheswaran, M., Preethi, V., and Naina Mohamed, S. (2020). Enhancing Biohydrogen Production from Sugar Industry Wastewater Using Metal Oxide/graphene Nanocomposite Catalysts in Microbial Electrolysis Cell. Int. J. Hydrogen Energ. 45, 7647-7655. doi:10.1016/j.ijhydene.2019.09.068

Jim, J., and Ramı, M. (2020). ScienceDirect Sustainable Biohydrogen Production by Chlorella Sp. Microalgae. A. Review. Int. J. Hydrogen Energ. 45 (15), 8310-8328. doi:10.1016/j.ijhydene.2020.01.059 
Jiménez-Llanos, J., Ramírez-Carmona, M., Rendón-Castrillón, L., and OcampoLópez, C. (2020). Sustainable Biohydrogen Production by Chlorella Sp. Microalgae: A Review. Int. J. Hydrogen Energ. 45, 8310-8328. doi:10.1016/ j.ijhydene.2020.01.059

Kadier, A., Kalil, M. S., Chandrasekhar, K., Mohanakrishna, G., Saratale, G. D., Saratale, R. G., et al. (2018). Surpassing the Current Limitations of High Purity H2 Production in Microbial Electrolysis Cell (MECs): Strategies for Inhibiting Growth of Methanogens. Bioelectrochemistry. Bioelectrochemistry 119, 211-219. doi:10.1016/j.bioelechem.2017.09.014

Kant, S., Mehariya, S., Kant, R., Kumar, Manu., Pugazhendhi, A., Kumar, Mukesh., et al. (2021). Science of the Total Environment Wastewater Based Microalgal Biore Fi Nery for Bioenergy Production: Progress and Challenges. Sci. Total Environ. 751, 141599. doi:10.1016/j.scitotenv.2020.141599

Khetkorn, W., Rastogi, R. P., Incharoensakdi, A., Lindblad, P., Madamwar, D., Pandey, A., et al. (2017). Microalgal Hydrogen Production - A Review. Bioresour. Tech. 243, 1194-1206. doi:10.1016/j.biortech.2017.07.085

Kucharska, K., Cieśliński, H., Rybarczyk, P., Słupek, E., Łukajtis, R., Wychodnik, K., et al. (2019). Fermentative Conversion of Two-step Pre-treated Lignocellulosic Biomass to Hydrogen. Catalysts 9, 858. doi:10.3390/catal9100858

Kumar, G., Bakonyi, P., Zhen, G., Sivagurunathan, P., Koók, L., Kim, S.-H., et al. (2017). Microbial Electrochemical Systems for Sustainable Biohydrogen Production: Surveying the Experiences from a Start-Up Viewpoint. Renew. Sust. Energ. Rev. 70, 589-597. doi:10.1016/j.rser.2016.11.107

Kumar, M., Oyedun, A. O., and Kumar, A. (2019). A Comparative Analysis of Hydrogen Production from the Thermochemical Conversion of Algal Biomass. Int. J. Hydrogen Energ. 44, 10384-10397. doi:10.1016/j.ijhydene.2019.02.220

Kumar, S., Sharma, S., Thakur, S., Mishra, T., Negi, P., Mishra, S., et al. (2019). Bioprospecting of Microbes for Biohydrogen Production: Current Status and Future Challenges. Bioproc. Biomol. Prod. 2040, 443-471. doi:10.1002/ 9781119434436.ch22

Lam, M. K., and Lee, K. T. (2013). Biohydrogen Production from Algae. Biohydrogen, 161-184. Elsevier B.V. doi:10.1016/B978-0-444-59555-3.00008-8

Lam, M. K., Loy, A. C. M., Yusup, S., and Lee, K. T. (2019). Biohydrogen Production from Algae. Biohydrogen, 219-245. Elsevier. doi:10.1016/b978-0444-64203-5.00009-5

Lee, D.-H. (2021). Biohydrogen Yield Efficiency and the Benefits of Dark, Photo and Dark-Photo Fermentative Production Technology in Circular Asian Economies. Int. J. Hydrogen Energ. 46, 13908-13922. doi:10.1016/j.ijhydene.2020.08.275

Limongi, A. R., Viviano, E., De Luca, M., Radice, R. P., Bianco, G., and Martelli, G. (2021). Biohydrogen from Microalgae: Production and Applications. Appl. Sci. 11, 1616. doi:10.3390/app11041616

Lu, C., Li, W., Zhang, Q., Liu, L., Zhang, N., Qu, B., et al. (2021). Enhancing PhotoFermentation Biohydrogen Production by Strengthening the Beneficial Metabolic Products with Catalysts. J. Clean. Prod. 317, 128437. doi:10.1016/ j.jclepro.2021.128437

Mahlia, T. M. I., Syazmi, Z. A. H. S., Mofijur, M., Abas, A. E. P., Bilad, M. R., Ong, H. C., et al. (2020). Patent Landscape Review on Biodiesel Production: Technology Updates. Renew. Sust. Energ. Rev. 118, 109526. doi:10.1016/ j.rser.2019.109526

Mahmudul, H. M., Rasul, M. G., Akbar, D., Narayanan, R., and Mofijur, M. (2021). A Comprehensive Review of the Recent Development and Challenges of a Solar-Assisted Biodigester System. Sci. Total Environ. 753, 141920. doi:10.1016/ j.scitotenv.2020.141920

Melis, A., and Happe, T. (2001). Hydrogen Production. Green Algae as a Source of Energy. Plant Physiol. 127, 740-748. doi:10.1104/pp.010498

Mofijur, M., Siddiki, S. Y. A., Shuvho, M. B. A., Djavanroodi, F., Fattah, I. M. R., Ong, H. C., et al. (2020). Effect of Nanocatalysts on the Transesterification Reaction of First, Second and Third Generation Biodiesel Sources- A MiniReview. Chemosphere 270, 128642. doi:10.1016/j.chemosphere.2020.128642

Mona, S., Kumar, S. S., Kumar, V., Parveen, K., Saini, N., Deepak, B., et al. (2020). Green Technology for Sustainable Biohydrogen Production (Waste to Energy): A Review. Sci. Total Environ. 728, 138481. doi:10.1016/j.scitotenv.2020.138481

Mosebach, L., Heilmann, C., Mutoh, R., Gäbelein, P., Steinbeck, J., Happe, T., et al. (2017). Association of Ferredoxin:NADP+ Oxidoreductase with the Photosynthetic Apparatus Modulates Electron Transfer in Chlamydomonas Reinhardtii. Photosynth. Res. 134, 291-306. doi:10.1007/s11120-017-0408-5

Mu, D., Liu, H., Lin, W., Shukla, P., and Luo, J. (2020). Simultaneous Biohydrogen Production from Dark Fermentation of Duckweed and Waste Utilization for
Microalgal Lipid Production. Bioresour. Tech. 302, 122879. doi:10.1016/ j.biortech.2020.122879

Muhammad, G., Alam, M. A., Mofijur, M., Jahirul, M. I., Lv, Y., Xiong, W., et al. (2021). Modern Developmental Aspects in the Field of Economical Harvesting and Biodiesel Production from Microalgae Biomass. Renew. Sust. Energ. Rev. 135, 110209. doi:10.1016/j.rser.2020.110209

Nagarajan, D., Dong, C. D., Chen, C. Y., Lee, D. J., and Chang, J. S. (2021). Biohydrogen Production from Microalgae-Major Bottlenecks and Future Research Perspectives. Biotechnol. J. 16, 2000124. doi:10.1002/biot.202000124

Nagarajan, D., Lee, D.-J., Kondo, A., and Chang, J.-S. (2017). Recent Insights into Biohydrogen Production by Microalgae - from Biophotolysis to Dark Fermentation. Bioresour. Tech. 227, 373-387. doi:10.1016/ j.biortech.2016.12.104

Nikolaidis, P., and Poullikkas, A. (2017). A Comparative Overview of Hydrogen Production Processes. Renew. Sust. Energ. Rev. 67, 597-611. doi:10.1016/ j.rser.2016.09.044

Oey, M., Sawyer, A. L., Ross, I. L., and Hankamer, B. (2016). Challenges and Opportunities for Hydrogen Production from Microalgae. Plant Biotechnol. J. 14, 1487-1499. doi:10.1111/pbi.12516

Oncel, S. S. (2015). Biohydrogen from Microalgae, Uniting Energy, Life, and green Future. Handb. Mar. Microalgae, 159-196. Elsevier. doi:10.1016/B978-0-12800776-1.00011-X

Osman, A. I., Deka, T. J., Baruah, D. C., and Rooney, D. W. (2020). Critical Challenges in Biohydrogen Production Processes from the Organic Feedstocks. Biomass Convers. Biorefinery, 1-19. doi:10.1007/s13399-020-00965-x

Park, J. H., Chandrasekhar, K., Jeon, B. H., Jang, M., Liu, Y., and Kim, S. H. (2021). State-of-the-art Technologies for Continuous High-Rate Biohydrogen Production. Bioresour. Technol. 320, 124304. doi:10.1016/ j.biortech.2020.124304

Parkash, A. (2016). Microbial Fuel Cells: a Source of Bioenergy. J. Microb. Biochem. Technol. 8, 247-255. doi:10.4172/1948-5948.1000293

Peng, L., Fu, D., Chu, H., Wang, Z., and Qi, H. (2020). Biofuel Production from Microalgae: a Review. Environ. Chem. Lett. 18, 285-297. doi:10.1007/s10311019-00939-0

Pophali, A., Singh, S., and Verma, N. (2020). Simultaneous Hydrogen Generation and COD Reduction in a Photoanode-Based Microbial Electrolysis Cell. Int. J. Hydrogen Energ. 45, 25985-25995. doi:10.1016/j.ijhydene.2020.01.053

Rajesh Banu, J., Kavitha, S., Yukesh Kannah, R., Bhosale, R. R., and Kumar, G. (2020). Industrial Wastewater to Biohydrogen: Possibilities towards Successful Biorefinery Route. Bioresour. Tech. 298, 122378. doi:10.1016/ j.biortech.2019.122378

Rather, M. A. H., and Srivastav, A. K. (2021). A Study on Biohydrogen Production Based on Biophotolysis from Cyanobacteria. Ann. Rom. Soc. Cel Biol. 25, 12500-12509.

Razu, M. H., Hossain, F., and Khan, M. (2019). "Advancement of Bio-Hydrogen Production from Microalgae," in Microalgae Biotechnology for Development of Biofuel and Wastewater Treatment (Springer), 423-462. doi:10.1007/978-98113-2264-8_17

Resnick, R. J. (2004). The Economics of Biological Methods of Hydrogen Production. Cambridge, United Kingdom: Massachusetts Institute of Technology.

Salakkam, A., Sittijunda, S., Mamimin, C., Phanduang, O., and Reungsang, A. (2021). Valorization of Microalgal Biomass for Biohydrogen Generation: A Review. Bioresour. Tech. 322, 124533. doi:10.1016/j.biortech.2020.124533

Sathyaprakasan, P., Kannan, G., and Kannan, G. (2015). Economics of BioHydrogen Production. Ijesd 6, 352-356. doi:10.7763/ijesd.2015.v6.617

Sengmee, D., Cheirsilp, B., Suksaroge, T. T., and Prasertsan, P. (2017). Biophotolysis-based Hydrogen and Lipid Production by Oleaginous Microalgae Using Crude Glycerol as Exogenous Carbon Source. Int. J. Hydrogen Energ. 42, 1970-1976. doi:10.1016/j.ijhydene.2016.10.089

Sharma, A., and Arya, S. K. (2017). Hydrogen from Algal Biomass: A Review of Production Process. Biotechnol. Rep. 15, 63-69. doi:10.1016/j.btre.2017.06.001

Shobana, S., Saratale, G. D., Pugazhendhi, A., Arvindnarayan, S., Periyasamy, S., Kumar, G., et al. (2017). Fermentative Hydrogen Production from Mixed and Pure Microalgae Biomass: Key Challenges and Possible Opportunities. Int. J. Hydrogen Energ. 42, 26440-26453. doi:10.1016/j.ijhydene.2017.07.050

Show, K.-Y., Yan, Y.-G., and Lee, D.-J. (2019b). in Biohydrogen Production from Algae: Perspectives, Challenges, and prospectsBiofuels from Algae. Second Edi (Elsevier B.V). doi:10.1016/b978-0-444-64192-2.00013-5 
Show, K.-Y., Yan, Y., Ling, M., Ye, G., Li, T., and Lee, D.-J. (2018). Hydrogen Production from Algal Biomass - Advances, Challenges and Prospects. Bioresour. Tech. 257, 290-300. doi:10.1016/j.biortech.2018.02.105

Show, K.-Y., Yan, Y., Zong, C., Guo, N., Chang, J.-S., and Lee, D.-J. (2019a). State of the Art and Challenges of Biohydrogen from Microalgae. Bioresour. Tech. 289, 121747. doi:10.1016/j.biortech.2019.121747

Siddiki, S. Y. A., Mofijur, M., Kumar, P. S., Ahmed, S. F., Inayat, A., Kusumo, F., et al. (2020). Microalgae Biomass as a Sustainable Source for Biofuel, Biochemical and Biobased Value-Added Products: An Integrated Biorefinery Concept. Fuel 307, 121782. doi:10.1016/j.fuel.2021.121782

Singh, H., and Das, D. (2020). Biohydrogen from Microalgae, Handbook of Microalgae-Based Processes and Products. Elsevier. doi:10.1016/b978-0-12818536-0.00015-4

Song, W., Ding, L., Liu, M., Cheng, J., Zhou, J., and Li, Y.-Y. (2020). Improving Biohydrogen Production through Dark Fermentation of Steam-Heated Acid Pretreated Alternanthera Philoxeroides by Mutant Enterobacter Aerogenes ZJU1. Sci. Total Environ. 716, 134695. doi:10.1016/ j.scitotenv.2019.134695

Volgusheva, A., Kukarskikh, G., Krendeleva, T., Rubin, A., and Mamedov, F. (2015). Hydrogen Photoproduction in green Algae Chlamydomonas Reinhardtii under Magnesium Deprivation. RSC Adv. 5, 5633-5637. doi:10.1039/c4ra12710b

Wang, J., and Yin, Y. (2018). Fermentative Hydrogen Production Using Pretreated Microalgal Biomass as Feedstock. Microb. Cel Fact. 17, 1-16. doi:10.1186/ s12934-018-0871-5

Wang, K., Khoo, K. S., Chew, K. W., Selvarajoo, A., Chen, W.-H., Chang, J.-S., et al. (2021). Microalgae: The Future Supply House of Biohydrogen and Biogas. Front. Energ. Res. 9, 1-9. doi:10.3389/fenrg.2021.660399

Wang, Y., Yang, H., Zhang, X., Han, F., Tu, W., and Yang, W. (2020). Microalgal Hydrogen Production. Small Methods 4, 1900514. doi:10.1002/smtd.201900514
Yilmaz, F., Balta, M. T., and Selbaş, R. (2016). RETRACTED: A Review of Solar Based Hydrogen Production Methods. Renew. Sust. Energ. Rev. 56, 171-178. doi:10.1016/j.rser.2015.11.060

Zhang, T., Jiang, D., Zhang, H., Jing, Y., Tahir, N., Zhang, Y., et al. (2020). Comparative Study on Bio-Hydrogen Production from Corn stover: PhotoFermentation, Dark-Fermentation and Dark-Photo Co-fermentation. Int. J. Hydrogen Energ. 45, 3807-3814. doi:10.1016/j.ijhydene.2019.04.170

Zhu, G., Yang, Y., Liu, J., Liu, F., Lu, A., and He, W. (2017). Enhanced Photocurrent Production by the Synergy of Hematite Nanowire-Arrayed Photoanode and Bioengineered Shewanella Oneidensis MR-1. Biosens. Bioelectron. 94, 227-234. doi:10.1016/j.bios.2017.03.006

Conflict of Interest: The authors declare that the research was conducted in the absence of any commercial or financial relationships that could be construed as a potential conflict of interest.

Publisher's Note: All claims expressed in this article are solely those of the authors and do not necessarily represent those of their affiliated organizations, or those of the publisher, the editors and the reviewers. Any product that may be evaluated in this article, or claim that may be made by its manufacturer, is not guaranteed or endorsed by the publisher.

Copyright (C) 2021 Ahmed, Rafa, Mofijur, Badruddin, Inayat, Ali, Farrok and Yunus Khan. This is an open-access article distributed under the terms of the Creative Commons Attribution License (CC BY). The use, distribution or reproduction in other forums is permitted, provided the original author(s) and the copyright owner(s) are credited and that the original publication in this journal is cited, in accordance with accepted academic practice. No use, distribution or reproduction is permitted which does not comply with these terms. 